\title{
ELOA O LA TENTACIÓN DE VIGNY POR EL MAL
}

\author{
Mạ del Carmen FERNÁN DEZ DÍAZ \\ Univ. de Santiago de Compostela
}

Sumergirse en el fondo de uno mismo puede ser una manera de encontrar a Dios... Pero puede hacer surgir también al diablo de sus abismos: de ahí la fascinación ejercida sobre los románticos por el mito de Fausto y toda una literatura diabólica que no es fácil de distinguir de la literatura fantástica ${ }^{1}$.

Alfred de Vigny fue ante todo poeta. Así lo atestigua su dilatada producción lírica que, durante casi cincuenta años, se extiende desde sus primeros ensayos de 1815 hasta 1863, fecha en la que compone El espíritu puro. Como todo principiante, comenzó escribiendo poemas breves, pero soñaba ya con ser capaz de elaborar largos relatos en verso de carácter épico y dramático que fuesen exponentes de los graves problemas de la condición humana. Y, entre estos últimos, los que apuntaban hacia preguntas y respuestas propiamente metafísicas resultaban primordiales para él, aunque su intención, es preciso advertirlo, fuese la de poner en solfa su validez.

En su mente se perfiló la idea de componer una gran epopeya religiosa, al estilo de Dante o de Milton², que en un principio pensaba titular El juicio final. Poco después, siguiendo a Byron33, derivó hacia Satán, especie de borrador poético del que iba a surgir Eloa o la hermana de los ángeles, composición que marca un hito en la primera estética de Vigny. Escrita en $1824,{ }^{4}$ relata un mundo etéreo, pero a la vez carnal; angelical y pagano, trágico en suma. La heroína del poema es un ángel femenino, encarnación del amor espiritual y de la piedad. La mujerángel se siente conmovida al conocer la historia de Luzbel, el rebelde, expulsado por Dios y sin embargo el más hermoso de esos seres de luz, intermedios entre la divinidad y el hombre, muchas veces también intercesores y guardianes de los humanos.

Nacen entonces en Eloa sentimientos encontrados y desconocidos: ternura e insatisfacción, curiosidad que es preciso saciar a toda costa, afán de redención. Quiere ver y conocer al Maldito, quiere salvarlo. No hemos de olvidar que la hipotética salvación de Satán fue uno de los temas predilectos del Romanticis-

${ }^{1}$ Garcia Aller, A. (Traductor), Diccionario de los escritores del mundo, Madrid (Everest) 1988. s.v. "Romanticismo". Título original: Dictionnaire des écrivains du monde", obra dirigida por P. Brunel y R. Jouanny.

${ }^{2}$ Milton, J. (1608-1674) publicó su El paraíso perdido en 1667. Se trata de una epopeya en 12 cantos que narra la aventura de Adán y Eva. Comienza con la caída de Satán y termina con la salida del Edén de la primera pareja humana.

${ }^{3}$ Byron (1788-1824). En 1815, y a petición de la comunidad judía de Londres, escribió $\mathrm{Me}$ lodías hebreas, inspiradas en la Biblia y musicadas más tarde por Isaac Nathan.

${ }^{4}$ En 1826, Vigny publica Poemas antiguos y modernos, en los que se encuadra Eloa. Estos poemas se reparten en tres libros: el místico, el antiguo y el moderno. 
mo. En su presencia, Eloa se siente fascinada. También Luzbel se conmueve ante la belleza pura de Eloa, pero el Mal termina por dominarlo. Se sirve de su poder para seducirla y para llevársela con él a los infiernos.

El ambiente bíblico que preside el conjunto de Eloa no logra enmascarar el irresistible empuje de Eros, de la sensualidad que se inscribe en no pocos de sus versos, y que recuerda muchas veces la atmósfera de $\mathrm{El}$ Cantar de los Cantares a través de los perfumes que, como el nardo, la mirra o la rosa, impregnan con sus aromas el universo maniqueo que desde un principio podemos observar en el poema. Incluso Luzbel dormita sobre una nube perfumada, lo que nos advierte de que la totalidad de la composición se basa en sensaciones inmateriales como las que provocan o sugieren las fragancias y también la música instrumental que tanto se asemeja a la voz de Eloa.

La voluptuosidad que preside el conjunto parece inducir a una conclusión precipitada. Y ésta no es otra que la idea de un mundo feliz... Nada más lejos de la realidad: en el universo íntimo de Vigny la sensualidad va inevitablemente unida a la sombra de la falta, del pecado, que no pocos críticos han atribuido a una educación demasiado puritana, regida por una madre sumamente autoritaria5. Siguiendo sus férreos principios morales, Vigny verá en los sentidos una amenaza, una inevitable tentación que de manera irremisible conlleva un castigo. Las vivencias felices, según el poeta, nunca pueden ser a la par inocentes.

La divinidad nos ha creado como un conglomerado de materia y espíritu, y este último pierde su pureza a causa de "Ias necesidades vergonzosas del cuerpo" 6 . A su vez, la materia pierde su felicidad sin complejos cuando se enfrenta a las exigencias del espíritu. Vigny pone así de manifiesto la imposible simbiosis armoniosa de las dos caras del hombre: Cada una por separado es pura; su mezcla, por el contrario, implica inexorablemente la falta, la caída, el pecado. En Eloa se puede apreciar fácilmente esta tesis. El ángel- mujer es preci pitado finalmente al abismo por haber cedido a la tentación de la sensualidad, de la materia, representada por Luzbel, el dios del cuerpo. Y es que el Luzbel de Eloa conserva toda la maldad que le adjudica el cristianismo. No posee la capacidad de ser redimido, pretensión que inútilmente tratará de llevar a cabo Eloa por medio del amor. La razón es muy simple: el papel de Luzbel consiste en denunciar la inevitable convivencia en cada ser humano de los dos principios contrarios, el espiritual y el material, y responsabilizar de paso a la divinidad de haber hecho a la criatura tan compleja y a la vez tan incapaz de lograr la reconciliación interior. De todo ello se infiere fácilmente que el poeta pone en duda la bondad intrínseca del Creador.

Vigny toma el nombre de Eloa del hebreo, lengua en la que es sinónimo de Elohím; es decir, Dios. A la divinidad se parece porque comparte al guno de sus atributos, pero a la vez -como ángel-, es intercesora, médium, tal como en la re-

\footnotetext{
${ }^{5}$ A. de Vigny, Oeuvres Completes I, Poésie, Théâtre, París (Gallimard) 1986, pp.905ss.

${ }^{6}$ Idem, "El taller del poeta: Borradores de Eloa", texto A 13, p.240.
} 
ligión cristiana se puede interpretar la figura de Cristo y tal como siempre se ha interpretado el papel desempeñado por los ángeles protectores. Se trata pues, de manera alegórica, de una enfrentamiento y hasta de un duelo entre el Bien y el Mal, entre el espíritu y la materia, que termina con el triunfo de esta última. Eloa, ángel perfecto y puro, pretende redimir a Luzbel, como Cristo, el mediador, hará con el conjunto de la humanidad. Pero, en ese universo de extremos irreconciliables, su intercesión se verá reducida a cenizas. El Mal consigue triunfar, ya que ambos principios son ineludibles e inseparables. No hemos de olvidar que, según la tradición hermética, "la luz sólo obtiene su sentido cuando disputa su ámbito a la oscuridad y se lo arrebata. Sin oscuridad no puede haber luz y sin materia no puede haber espíritu"7.

Victor Hugo, en un artículo publicado en La Musa Francesa, y en mayo de 1824, dijo: "Si alguna vez una composición literaria ha llevado la huella inefable de la meditación y de la inspiración es este poema. Una idea moral, que abarca a la vez las dos naturalezas del hombre... la hermana de los ángeles empujada por la curiosidad, la compasión y la imprudencia".

Eloa nace de una de las lágrimas derramadas por Cristo ante Lázaro, su amigo muerto. Y, como Cristo, como todos los humanos, será abandonada a su libre al bedrío. Jesús, en el Monte de los Olivos, tratará de entender el sentido y el valor de su sacrificio, pero se enfrentará al terrible silencio del Padre. Eloa, desorientada, sufriendo de ese mismo silencio, confundirá los límites de su función, su total libertad la llevará por un camino descendente y sin retorno. No en vano el poema empieza con una cita del Génesis: "Fue la serpiente, la escuché y me engañó". De este modo, el poeta nos prepara para un desenlace trágico y previsible: "-Cré́ que te había salvado", le dice Eloa a Luzbel. "-No; soy yo quien te condena", respondeel Maligno.

El Occidente cristiano heredó de forma imborrable la dualidad propagada por la religión, la animadversión por lo carnal, fuente de pecado, frente a la propuesta de la total pureza que entronca con el espíritu y con la noción del Bien absoluto. Muchos de los escritos románticos reflejan esa bipolaridad y también la fisura interna del alma humana, que se debate entre el modelo que le propone la religión y la realidad cotidiana, con sus deseos y sus exigencias. Rebuscar en las debilidades propias y en la ajenas fue un rasgo característico del Romanticismo. También Vigny llevó a cabo esa introspección, internándose de ese modo en la corriente literaria de su época y refugiándose en la poesía para plantearse, bajo el prisma del arte, las mayores y más inquietantes preguntas sobre el hombre y su destino. El Mal absoluto, encarnado por el ángel caído, es la imagen que el poeta dibuja de la materialidad profunda del hombre. "Soy el rey secreto de los secretos amores", afirma Luzbel. Frente a él, la pureza sin mancha de Eloa representa la tentación por el Bien, la espiritualidad que también anida en la naturaleza humana.

\footnotetext{
${ }^{7}$ Introducción a Goethe, Fausto, Madrid (Espasa-Calpe) 1998, p.22.
} 
Esta unión de los contrarios, esta posibilidad de redención a través de la bondad, es una especie de pirueta interior que hace que se tambalee el esquema previamente establecido. Pero sucumbir ante el Bien significa renunciar a lo que se es, reconocer que el cuerpo y la materia han fracasado de manera definitiva. Luzbel lo sabe. Sus promesas de felicidad han de ser necesariamente falsas, conociendo de antemano que la fusión de los contrarios es inviable. De este modo, la permanencia de ambos principios simboliza a la vez el fracaso de la utopía, la edad de oro definitivamente perdida, y el triunfo de la tentación, el amor y la muerte.

Es preciso advertir, llegados a este punto, que la noción del mal encarnado en el Diablo es una de las más firmemente arraigadas en el cristianismo. No obstante, el relato de los ángeles caídos no aparece de manera completa en el Antiguo Testamento, en el que sólo se hace referencia a Ha-satan, 'el Adversario'. "El relato más antiguo de los Ángeles que en realidad se sabía que se habían rebelado, siendo castigados por ello, aparece en el apócrifo Libro de los Secretos de Enoc (170 ó 110 a.C.). Sin embargo, la creencia subsiste independientemente del dogma. Hacia la época en la que se compiló el Nuevo Testamento, la influencia de Enoc había sido bastante asimilada, junto con las concepciones duales del persa Zoroastro"8.

La atmósfera metafísica en la que se encuadra el poema revela una necesidad de trascendencia que será común en la mayor parte de los escritores románticos9. Esa duración se encarna a veces en la posibilidad del amor eterno, sin límites, como gran sustituto del absoluto. Luzbel así lo entenderá, verá la fuerza del sentimiento amoroso, se sentirá tentado ante una imagen de mujer que sobrepasa lo sensorial y profundiza en las fibras más íntimas de la ternura. Ella podría el evarlo hacia lo sublime.

Ese vértigo que el Maligno experimenta ante el ángel femenino se plasma en el poema a través de imágenes que insisten en la idea de la atracción espiritual. Tal es el caso de las alas de Eloa, forjadas en plata. En la tradición cristiana, las alas simbolizan el pneuma, la espiritualidad. Y la plata, en el sistema de correspondencias de los metales y los planetas, se asimila con la mujer. También con la luna, símbolo femenino por excel encia, y contrapuesto al oro, masculino y solar ${ }^{10}$. Presenta además la plata otra característica, la de la pureza, que engloba la nitidez de la conciencia y de la intención. De ese modo, en la simbólica cristiana, llegó a representar la sabiduría divina.

Los cabellos de Eloa, segunda imagen, son dorados, siguiendo así la misma idea, la de las fuerzas psíquicas emanadas de la divinidad, ya que su primera

\footnotetext{
${ }^{8}$ Godwin, M., Angeles, Barcelona (Robinbook) 1995, pp.73-74.

9 "La proliferación de la temática religiosa durante el Romanticismo se explica en gran parte por una necesidad interior, que conlleva unas irrefrenables ansias de trascendencia”, Reyero, C., El arte del siglo XIX, Madrid (Anaya) 1992, p.14.

${ }^{10}$ Chevalier, J. \& Gheerbrant, A., Dictionnaire des symbols, París (Robert Laffont) 1982, s.v. "Ange / Argent".
} 
morada fue el cielo, plenitud de las aspiraciones humanas, meta única de la búsqueda incasable del absoluto, lugar de perfección espiritual. Luzbel, por el contrario, se compara con el cisne, ave inmaculada, pero a la vez encarnación de la virilidad solar y fecunda. Es cisne similar al de la leyenda griega, las que nos habla de Zeus y de Leda, la que nos permite imaginar que el dios se transforma para seducir a la mujer y, una vez consumado su deseo, exhala un canto, un lamento que conlleva la profunda insatisfacción que sigue experimentando.

Hay, en la leyenda helena, un poso que recuerda la dualidad cristiana a la que estamos aludiendo, una advertencia de que lo puro y lo impuro son las dos caras del hombre, de que la tentación va impresa en cada ser, aunque no lo sepa. La posesión carnal, según Vigny, no sacia, no consigue la trascendencia añorada. El gran fracaso de Eloa, a nivel meramente humano, más allá de la alegoría metafísica en la que el poema está inmerso, es el de haber sido incapaz de despertar en su oponente masculino la ternura, definitivamente muerta en su interior. Así lo expresan los siguientes versos: “-¿Por lo menos eres más feliz, estás contento? -Más triste que nunca", le replica Luzbel.

La frustración, no hemos de olvidarlo, fue una de las constantes del Romanticismo. También Vigny la comparte. Se trata de la imposible realización de las infinitas exigencias que al berga el alma humana, enfrentada a una realidad que nunca podrá satisfacerla. Parecidas formulaciones aparecen en otros poetas de la misma corriente. De ese modo, encontraremos " por un lado un yo de la exaltación, que nos manifestará la apasionada e ilusionada búsqueda del ideal (y, en ocasiones, su creencia de que lo ha alcanzado), y por otro aparecerá un yo de la lamentación, que será aquel que cante desde la angustia del fracaso, desde el dolor del desengaño"11.

La exaltación y su más que previsible declive se cifrarán muchas veces, para el poeta, en la imagen femenina. Maeterlinck, años después, tendrá muy presente esta idea, que aflora una y mil veces en la literatura occidental y tiene raíces indudablemente cristianas. Dice Maeterlinck en su poema Alma de noche:

\author{
¡Espero tus dedos puros en mi rostro, \\ Parecidos a ángeles de hielo. \\ Espero que mojen mis miradas, \\ La hierba muerta de mis miradas, \\ Donde tantos corderos cansados están esparcidos $j^{12}$.
}

Siempre la Mujer, la Mujer que da la vida y la muerte, que alberga la capacidad de redención, pero al mismo tiempo promete una dicha que está muy lejos de poder asegurar. Así lo habían visto ya los griegos en la Antigüedad, y también Lamartine, contemporáneo de Vigny, en su poema La caída de un ángel, en el

\footnotetext{
${ }^{11}$ Lopez Casanova, A., La poesía romántica, Madrid (Anaya) 1991, p.38.

12 "El simbolismo belga", en Correspondance, Univ. de Cáceres, Octubre 1993, n 3, p.115.
} 
que Cedar se enamora de la mortal Daidha y es condenado a renacer sin fin hasta que sepa desprenderse de lo material. En ambos poetas se pone de manifiesto que el Romanticismo, al moverse en los dos planos mencionados, el de la exaltación y el del lamento, cae también en dos extremos contrarios: uno será el del Titanismo, y de él surgirá la imagen del rebelde que se enfrenta al orden establecido. El otro será el del Satanismo, que conducirá al hombre a convertirse en ángel de las tinieblas, en rebelde caído y vencido, profundamente frustrado al constatar que debe vivir en la cárcel de una realidad con límites y ataduras. Hacia este último Satán apunta Vigny, un Luzbel que ha sido excluido de la dicha, que ya no cree ni quiere creer en supuestos paraísos, y que está dispuesto a sacrificar a otros, como si la destrucción ajena fuera capaz de saciar su inagotable sed de infinito.

Vigny, es preciso reconocerlo, se muestra profundamente pesimista. Su paleta es sombría. Su universo maniqueo, terrestre, en constante lucha y rebelión no contra Dios, sino más bien contra sí mismo. Sucumbe pues a la tentación del mal, de un mal que no proviene de una castigo impuesto y divino, sino de una fisura interior, propia, que por sus creencias no fue capaz de resolver. 